\title{
RECONSTITUTION DES CHAINES OPERATOIRES DE FABRICATION DES CERAMIQUES NEOLITHIQUES DANS LE BASSIN PARISIEN \\ RECONSTRUCTION OF THE PROCESS TECHNIQUES OF THE NEOLITHIC POTTERY IN PARIS BASIN: A RESEARCH ASSESSMENT
}

\author{
(C)2015
}

\author{
Fr. Giligny, Professeur
}

Université Paris 1 Panthéon-Sorbonne, Paris (France)

\section{Résumé:}

Depuis une quinzaine d'années, les travaux de reconstitution des chaînes opératoires de façonnage de la céramique ont été réalisés sur des corpus néolithiques du Bassin parisien et du nord de la France. Ces travaux sont menés par le biais de mémoires universitaires ou de programmes de recherches et sont encore largement inédits. Ils sont basés sur les principes énoncés dès les années 1950 par les archéologues et ethnologues des techniques sous l'égide en France d'A. Leroi-Gourhan et d'Hélène Balfet (1953) et ont été connu un regain d'intérêt dans les années 1990 à 2000 (Astruc et al. 2004, Giligny and Méry 2010). Ils sont également fondés sur une tradition des études de matériaux céramiques menés en parallèle dès les années 1980 (Constantin and Courtois1980).

Le principe de ces travaux est basé sur une approche double : une analyse et description des stigmates et macrotraces de façonnage ainsi que des reconstitutions expérimentales afin de tester les chaines opératoires. Les premières données nous permettront une approche trans-culturelle et une reconstitution de l'histoire des méthodes de production des premières céramiques dans le nord de la France. Ils permettent aussi d'appréhender de manières anthropologique les relations entre technique et société.

Abstract: Since about fifteen years, works of reconstruction of the pottery operational sequence of manufacturing were realized on corpuses of the Neolithic of Paris Basin and the North of France. These works were led within the framework of university memoirs or of research programs and are still widely unpublished. They are based on the principles expressed from the 1950s by archaeologists and ethnologists of techniques trained in France by A. Leroi-Gourhan as Hélène Balfet (1953) [1] renewed in the 1990s to 2000 [2; 3]. They also lean on a tradition of the ceramic materials studies led in parallel since the 1980s [4].

The principle of these works bases on a two-pronged approach: an analysis and a description of stigmas and shaping fabric marks and the experimental reconstructions to test the hypotheses of operational sequences. The first data repository will have to allow later a cross-cultural approach and a reconstruction of the history of the production methods of the first potteries in northern France. They also allow to work on the anthropological analysis of the relationship between technique and society.

Keywords: Neolithic, France, pottery technology, operational sequence

\section{УДК 902 \\ БЫТОВОЕ И САКРАЛЬНОЕ ИСПОЛЬЗОВАНИЕ КЕРАМИКИ У САРМАТОВ ЮЖНОГО ПРИУРАЛЬЯ И ЗАПАДНОГО КАЗАХСТАНА}

(C) 2015

\author{
Л.А.Краева, кандидат исторических наук \\ Оренбургский государственный педагогический университет, Оренбург (Россия)
}

Аннотаци. В статье рассматривается керамика из сарматских погребений Южного Приуралья и Западного Казахстана. Керамика помещалась в могилы всех слоев кочевого населения. В захоронения знати обычно ставили более дорогую импортную посуду. Сарматская керамика активно использовалась как в хозяйстве, так и в религиозных церемониях. В могилах находят специально изготовленные для обряда погребения сосуды, а также уже использованную в быту посуду, в том числе отремонтированную. Автором выделены признаки бытового использования керамики до помещения их в могилу: 1) наличие нагара на внутренних и внешних стенках сосудов; 2) жировые пятна и следы подтеков от убежавшей жидкой пищи; 3) следы ремонта; 4) старые сколы керамики (отбитые ручки, края сосудов и т.д.); 5) следы потертости и бытовая полировка; 6) цветовые изменения поверхностей сосуда и слоев излома черепка. К признакам специального изготовления сарматской керамики для обряда погребения отнесены: 1) использование неочищенного сырья с грубыми естественным примесями; 2) некачественный промес теста (неравномерное распределение частиц примесей); 3) небрежность в изготовлении формы; 4) кратковременное воздействие температур ниже $450^{\circ}$ С при обжиге; 5) отсутствие нагара на стенках сосуда; 6) отсутствие следов ремонта.

Исследование поверхности сосудов и экспериментальные работы позволили выдвинуть предположения о функциональном использовании некоторых типов керамики.

Ключевые слова: керамика; сарматы; Южное Приуралье; Западный Казахстан; погребальная керамика; бытовое использование; сакральное использование. 
Керамическая посуда у многих народов активно эксплуатировалась в быту, а также всегда использовалась в похоронной церемонии и других религиозных обрядах.

Керамика ранних кочевников Южного Приуралья и Западного Казахстана с VI в. до н.э. до IV в. н.э. является самой массовой категорией погребального инвентаря.

В одно погребение сарматы помещали от одного до четырех сосудов, но обычно ставился только один сосуд. Количество сосудов не зависело от числа погребенных.

Керамика помещалась в погребения всех слоев кочевого населения. Однако в богатые погребения элиты сарматского общества, как правило, ставили более дорогую, преимущественно привозную посуду: деревянные чаши, окованные пластинами из драгоценных металлов, золотые и серебряные сосуды, керамику, изготовленную на гончарном круге [1, с. 239-240; 2, с. 25, 29, 90, рис. 1, 5, 15].

Керамические сосуды ставили не в каждое захоронение, чаще всего их помещали в погребения женщин и детей, но жесткой взаимосвязи с полом погребенного все же не прослеживается. Какая-либо связь между размещением посуды и формой могильной ямы также не обнаружена.

Посуда сопровождала не только человеческие захоронения, но и погребения животных. Так в могильнике Шумаево II лепной сосуд был помещен в погребение козы (к. 9 п. 7), похороненной по человеческому обряду [3, с. 138, рис. 81: 1-2] (рис. 1: 1).

Известны местонахождения керамики в насыпи кургана, на деревянном перекрытии могилы, а также в засыпи рва или могильной ямы, что связано с ритуальным кормлением духов и тризной. Наибольший процент составляет посуда, поставленная в погребения в качестве приношения усопшему, в чем проявлялась любовь и забота о близких, в частности, об их жизни после смерти [4, с. 204].

Наиболее часто встречается помещение целых сосудов, реже фрагментов или разбитых в ходе погребальной церемонии горшков. Примечательно, что в некоторых захоронениях большие толстостенные фрагменты зауральской керамики со значительной концентрацией талька (1:1 и 1:2) находились рядом со стрелами. Фрагменты керамики «мылились» на ощупь и имели старые завальцованные изломы (Шумаево I) [3, с. 54, рис. 34: 5].Возможно, помещение таких фрагментов именно в погребения воинов-лучников неслучайно. Учитывая свойства талька, они служили в качестве инструмента, предотвращающего потливость рук и уменьшающего силу трения тетивы.

Наблюдается определенный стандарт в местоположении керамики в погребении. Посуду ставили: 1) за головой; 2) в ногах; 3) у таза; 4) у руки. Чаще всего размещали керамику в ногах или за головой покойного. По мнению В.А. Дёмкина и Я.Г. Рыскова, местопо- ложение керамики могло быть связано с содержимым сосудов. Полученные исследователями данные по материалам левобережного Илека показывают, что в 80\% сарматских погребений прослеживается закономерность: сосуды с водой расположены у головы, с кашей или бульоном - в ногах, а в погребениях, где имеется лишь один сосуд с водой, как правило, отмечается присутствие костей животных [5, с. 78-79].

Как и при использовании в жизни, сосуды устанавливались в погребение на дно. Необычное исключение составляют два сосуда котловидной формы высотой 29,6 и 34,3 см из могильника Шумаево I (к. 4 п. 1), которые были обнаружены в заполнении могилы в перевернутом состоянии плотно прижатыми друг к другу [3, с. 30] (рис. 1: 2-3). Оба сосуда имели многочисленные отверстия для ремонта, а внутри находился пузырчатый черный слой нагара толщиной 3-6 мм, который покрывал все стенки и дно.

В могилы помещали посуду, изготовленную как специально для погребальной церемонии, так и использованную в быту.

Исследование технологии изготовления данной керамики (700 сосудов), производимое по методике А.А. Бобринского, позволило затронуть проблему роли керамики в погребальном обряде ранних кочевников на качественно ином уровне. Методика анализа посуды базируется на бинокулярной микроскопии, физическом моделировании, сравнительном анализе по эталонным сериям и трасологии $[6 ; 7 ; 8$; 9 , с. 51-60].

БЫТОВАЯ ПОСУДА. Следует отметить, что четкие критерии бытового использования керамики до сих пор не выделены. Отчасти к косвенным признакам бытового использования посуды можно отнести: 1) наличие нагара на внутренних и внешних стенках сосудов; 2) жировые пятна и следы подтеков от убежавшей жидкой пищи; 3) следы ремонта; 4) старые сколы керамики с завальцованными краями (отбитые ручки, края сосудов и т.д.); 5) следы потертости, бытовая полировка; 6) цветовые изменения поверхностей сосуда и слоев излома черепка. Однако исследователям надо быть предельно осторожными с однозначной интерпретацией этих признаков. Остановимся на некоторых их них.

Наличие нагара на стенках сосудов. С проблемой нагара на посуде хотя бы раз в жизни сталкивается даже самая аккуратная современная хозяйка. Нагар различной толщины (0,2-6 мм) встречается и на древней сарматской керамике. Обычно он наиболее интенсивно покрывает внутреннюю часть сосудов: по плечу, реже по венчику и придонной части, в то время как на дне отсутствует или присутствует крайне редко. С внешней стороны нагар чаще встречается по венчику и плечу. На остальных частях сосудов слой нагара, как правило, отсутствует.

Следы нагаров и копоти имеет значительная часть сарматской керамики, но не всегда они могут быть 
связаны с варкой пищи. В ряде случаев, как показывают экспериментальные работы, такие следы образуются при обжиге посуды. Для того чтобы говорить о пищевом происхождении нагаров необходимо специальное их изучение и наблюдение за характером их расположения на поверхностях сосудов.

Особой толщиной нагаров выделялись сосуды из могильников Шумаево II (к. 9 п. 4 с. 1) (рис. 1: 4), Прохоровка I (к. 4 п. 2 с. 2) (рис. 1: 5), Покровка II (к. 8 п. 10 с. 2) (рис. 1: 6) [3, с. 129 , рис. 83: 2; 10, рис. 1: 3; 11, с. 38-39, рис. 61: 2]. Сосуды из данных захоронений имели небольшие размеры (13,5 см; 10,7 см; 9,5 см), внутренние их поверхности были покрыты толстым слоем нагара толщиной 3-4 мм, а внутрь помещены камни, «тальковые молоточки» или фрагменты керамики. В шумаевском сосуде, по определению А.А. Гольевой, сжигались веточки и травы, но не конопля, а приготовление или хранение в нем какой либо пищи исключено. Сосуд также мог быть приспособлен для освещения при погребальной церемонии [3, с. 218]. Видимо, все эти сосуды использовались в каких-то сходных ритуальных церемониях, что по функциональному назначению сближает их с курильницами, хотя по форме они ничем не отличаются от обычных горшков. На наш взгляд, описание такой керамики должно производиться по алгоритму описания обычного сосуда и только при достаточно веской аргументации высказываться мнение об использовании его в качестве курильницы, чтобы не вносить путаницу в терминологию.

Наиболее полному исследованию такой категории сарматской керамики, как курильницы, была посвящена специальная работа К.Ф. Смирнова «Курильницы и туалетные сосудики Азиатской Сарматии». В ней он изложил свои взгляды на назначение, типологию, происхождение и хронологию этих предметов. Курильницы и туалетные сосудики рассматривались в единой классификации, а функциональное назначение этих сосудиков в пределах одного типа определялось условно по их общему сходству между собой. Сосудики, имеющие следы действия огня, относились автором к курильницам, в которых воскуривались ароматические вещества богам и предкам. Помещение красящих веществ рядом или внутри отдельных курильниц служило основанием отнесения их к туалетным сосудикам для хранения косметических средств [12, с. 166-179]. Как показывают проведенные исследования, к сожалению, визуальная интерпретация нагара не всегда может быть корректной, а также не все курильницы имеют следы нагара и копоти внутри. Необходимо более детальное изучение этого типа керамики с привлечением результатов экспериментальных работ и анализа нагаров.

Интересное использование керамики в обрядовой церемонии, связанной с огнем, зафиксировано в могильнике Бердянка V (к. 5 п. 3). В катакомбе на столике, сложенном из угля и гумуса, вместе с обо- жженными камнями и мелом находился небольшой сосудик со следами маслянистого вещества на внешней и внутренней поверхностях. Рядом с ним лежала перевернутая вверх дном миска (рис. 1: 7) со следами в виде темно-коричневых «звездочек» на внутренней и частично на внешней поверхностях [13, с. $129 ; 14$, c. 122-123, 128-129] (фото 1: 1).

Технологический анализ показал, что при изготовлении курильниц были зафиксированы в основном более архаичные навыки, характерные для гончарства савроматского периода: преобладание рецептов из ожелезненной «тощей» глины, ила и глиноподобного сырья с добавлением органических добавок и шамота; отсутствие выбивания при формообразовании; заглаживание пальцами. Только в формовочных массах курильницы из Линевского одиночного кургана (п. 3) (рис. 1: 8) и сосудов редких форм (КМ Филипповка к. 7, КМ Акоба II к. 1 п. 3) была зафиксирована примесь шерсти $[15$, с. 17 , рис. $106 ; 16$, с. 48 , рис. 5: 5; 17, с. 186-188, 197] (рис. 1: 9-10). Видимо, примесь шерсти имела культовое назначение и подчеркивала связь животных с этими ритуальными сосудами.

Комплексный подход в изучении керамики позволил сделать предположение о функциональном назначении сосуда редкой формы из могильника Акоба II (к. 1 п. 3) [18, с. 197-201]. Сосуд с двумя ножками со сквозными отверстиями имитировал форму вымени козы. Посуда в форме вымени известна у разных скотоводческих народов (алтайцы, киргизы, башкиры, арауканы), и ее можно разделить на две группы: 1) сосуды, изготовленные непосредственно из вымени животных (рис. 1: 11-12); 2) сосуды, имитирующие вымя животных, изготовленные из камня, дерева, керамики [19, 93-97, рис. 1-3, 5-6; 20, с. 141-143] (рис. 1: 13-14). Именно ко второй группе относится сосуд из могильника Акоба II (рис. 1: 9), а также сосуд из КМ Филипповка I (к. 7), имитирующий коровье вымя с четырьмя сосцами (рис. 1: 10). За последнее время стали известны еще 2 сарматских сосуда подобного типа из курганного могильника Филипповка (к. 29) и одиночного курган Яковлевка II (п. 7) ${ }^{1}$.

Вполне возможно, что данные предметы могли использоваться в качестве воронки, емкости для выжимания творога или даже священной Сомы, так называемого «вымени Сомы», упоминаемого в Ригведе [21, с. 32]. Однако наблюдения под микроскопом за следами на сосуде позволили выдвинуть альтернативную гипотезу использования акобинского сосуда. Внешняя поверхность керамики была сильно повреждена отслоившимися участками. Наряду с «выколами», образовавшимися в результате обжига, отдельные поврежденные участки связаны с ритуальным использованием сосуда и перекрыты слоем нагара (фото 1: 2). Сходные следы повреждения

1 Выражаем глубокую признательность А.Х. Пшеничнюку, Л.Т. Яблонскому и С.В. Сиротину за предоставленные сведения. 
внешних поверхностей зафиксированы нами на курильницах с одним боковым отверстием, возможно, они возникают под частым воздействием огня (рис. 1: 15, 17-18; фото 1: 3-4). Очень тонкий слой нагара фиксировался на таких участках на высоте 1-1,5 см от края устья на внешней поверхности, а также по срезу венчика акобинского сосуда. На внутренней поверхности слой нагара читался лучше и проходил по кругу полосой шириной $1-1,5$ см от края устья. Следы от нагара были зафиксированы на внутренней поверхности сквозных отверстий «выступов-ножек». Учитывая наличие только двух неустойчивых ножек и расположение нагара, можно предположить, что сосуд ставился в перевернутом положении на какоето горящее вещество, дым от которого выходил из отверстий «ножек-сосков». В таком случае, по всей видимости, мы имеем дело с предметом, используемым в ритуальных целях, возможно при воскуривании трав. Косвенно подтверждает эту гипотезу и абстрактный орнамент на сосудике, напоминающий взвивающиеся языки пламени. По данным исследователей, известно, что кочевникам было знакомо курение конопли, при котором они использовали целый комплекс оборудования [22, с. 173]. По сообщению И. Идеса и А. Бранда, для курения приобские остяки пользуются каменным сосудом, куда они втыкают специально сделанный для этого чубук $[23,103]$. В Азербайджане известен процесс курения с помощью полых палочек, вставленных в наполненный дымом от пахучих трав мешок.

Жировые пятна и следы подтеков от убежавшей жидкой пищи. Регулярное использование посуды при варке жирной пищи приводит к образованию на ней разного рода пятен. Исследование поверхностей древних сарматских сосудов позволило выделить различные варианты пятен, не связанных с обжигом: 1) черные и коричневые «звездочки» размерами 0,3-1 см (фото 1: 1);2) черные и коричневые пятнышки округлой и аморфной формы с четкими контурами размерами от мельчайших до 0,8 см (фото $2: 1)$; 3 ) коричневые и черные округлые пятна с размытыми краями размерами 0,1-0,8 см (фото 2: 2); 4) коричневые, полностью размытые, аморфные пятна размерами 0,3-1,3 см (фото 2: 3).

Без проведения специального химического анализа сложно говорить о составе пятен. Однако обращая внимание на расположение, маслянистость, цвет и форму пятен, можно высказать предположение о причинах их возникновения. Проведенные экспериментальные работы свидетельствуют, что следы в виде «звездочек» могли образоваться в результате целенаправленного разбрызгивания жидкого вещества (фото 1: 1). В некоторых случаях пятна можно связать с пятнистым обвариванием [6, с. 238-239] (фото 2: 4-5). Не исключено, что жирные коричневые пятна были оставлены маслами для косметических процедур, которые хранились в сосудах (фото 2: 3).
Неслучайно их наличие чаще фиксируется на поверхностях небольших сосудиков высотой до 10 см.

Следы подтеков от убежавшей жидкой пищи при варке обычно фиксируются на внешних поверхностях сарматских сосудов от края венчика (фото 1: 5). Наряду с ними внутри и снаружи таких сосудов присутствует нагар.

Иногда следы в виде «искусственных» подтеков, аморфных разводов и пятен встречаются по тулову и венчику сосудов, но связаны они с целенаправленным процессом разбрызгивания какой-то красящей жидкости сразу после обжига керамики (фото 2: 4-5). Отличаются они от «бытовых» следов более светлым тоном и отсутствием слоя сажи на самих подтеках, местом распределения на внешней поверхности сосуда (не всегда идут от края венчика, обычно расположены по плечу, тулову, донной части), а также формой (вертикальные подтеки сочетаются с разводами разной конфигурации). Подтверждением непищевого их происхождения является отсутствие нагара внутри таких сосудов. Примеры покрытия посуды пятнами с потеками, носящими характер оберега, известны по этнографическим источникам в Средней Азии и Сибири. Так, по сообщению Е.M. Пещеревой, узбекские гончары захватывали горстями разведенную в воде железистую глину, бросали ее на сосуды и брали их запачканными руками, оставляя на керамике следы пальцев. Глина при этом растекалась по стенкам, давая длинные потеки [24, с. 79-81].

Следы ремонта. В исследованной выборке керамики $15 \%$ сосудов имели следы ремонта. Традиция ремонта посуды имеет давние корни. Она широко известна на территории Южного Приуралья и других регионов у различных народов в эпоху неолита, энеолита, бронзы [25, с. 179].

Следы ремонта на керамической посуде ранних кочевников Южного Приуралья и Западного Казахстана представлены в виде просверленных сквозных отверстий, располагающихся обычно парами по краям трещин. Количество отверстий варьирует от 2 до 22. Сосуд с наибольшим количеством отверстий (22) для ремонта был исследован в могильнике Шумаево I (к. 4 п. 1 с. 1) (рис. 1: 3). Отверстия на отремонтированной посуде имеют, как правило, круглую форму. Высверливание их производилось твердым предметом в основном с внешней стороны сосуда обычными круговыми движениями, о чем свидетельствуют концентрические полосы и штрихи на внутренних поверхностях отверстий. Наличие специальных скоб, скрепляющих эти отверстия, как в позднем бронзовом веке, очень редкое явление. Примером может служить ремонт сосуда из могильника Прохоровка I (к. Б п. 1), у которого верхняя часть венчика была прикреплена с помощью бронзовой проволоки, продетой через просверленные сквозные отверстия [26, с. 185, рис. 9: 6].

Видимо, обычно отверстия для ремонта соединялись шнурами из органических материалов рас- 
тительного или животного происхождения (кожа, ткань и т.д.), которые не сохраняются. Корни такой традиции видятся в широком использовании кочевниками сшитой кожаной посуды.

Единичный случай использования замазки трещины при ремонте в верхней части позднесарматского сосуда зафиксирован нами в Западном Казахстане 2 (могильник Целинный к. 32) [27, с. 106-108, рис. $35,21]$. Твердое черное вещество, которое с трудом царапалось металлической иглой, заполняло вертикальные трещины шириной до 2 мм, длиной до 5-6 см, которые шли от края венчика сосуда (фото 1: 6).

После ремонта сосуды продолжали использоваться в быту до помещения в погребение, в некоторых из них даже фиксируется слой нагара, перекрывающий отверстия для ремонта (фото 2: 6).

Старые сколь керамики с завальцованными краями, следы потертости и бытовая полировка.

Иногда в погребения помещали керамику с отбитыми краями венчиков и утраченными функциональными частями сосудов (ручки, носики). Примером такого наиболее активного бытового использования служит кувшин из погребения 4 одиночного кургана у с. Благославенка [28, с. 188] (рис. 1: 19). В результате исследования было выявлено несколько признаков его хозяйственного использования, прежде чем он попал в могилу. Ручка и венчик кувшина были отбиты в древности, и поверхности сколов завальцованы (затерты), в средней части тулова и по горлу располагались сквозные отверстия для ремонта. Нижняя часть сосуда имела блестящую поверхность в результате полировки мягким материалом после обжига в ходе бытового использования. По этнографическим данным, известно, что женщины-гуцулки Карпат наводили на свою глиняную посуду «глянец» после варки пищи мягким материалом типа замши или ветошью, в результате чего она становилась блестящей ${ }^{3}$.

Кроме того, как показал проведенный эксперимент по выявлению низкотемпературного обжига, благославенский сосуд был обожжен при температурах ниже $450^{\circ} \mathrm{C}$ [29, с. 20-23]. После помещения образца в воду из его формовочной массы можно было скатать жгутик, следовательно, сосуд мог использоваться только для хранения сыпучих продуктов, а не для жидкости.

Известны случаи, когда вышедшему из употребления сосуду давали «вторую жизнь», что позволяло его заново использовать в быту. Так, в заполнении рва кургана 2 могильника Изобильное I была найдена чаша (рис. 1: 25), сделанная из продольной половинки тулова сосуда со значительной примесью талька в

2 Выражаю глубокую признательность С.Ю. Гуцалову и казахским коллегам А.А. Бисембаеву, М.Н Дуйсенгали, Я.А. Лукпановой, Д.В. Марыксину, А. М. Мамедову, М. К. Мурзагалиевой, А. Онгару, М. Н. Сдыкову, М. М. Утесову за возможность работы с керамическими коллекциями Западного Казахстана. формовочной массе (концентрация 1:2) ${ }^{4}$. Края половинки были выровнены и тщательно затерты [30, с. $3-4 ; 31$, с. 64 , рис. 38,7$]$.

Цветовые изменения поверхностей сосуда и слоев излома черепка. Поверхности некоторых сарматских сосудов имели более толстый осветленный слой с внешней стороны, в отдельных случаях наблюдалась пятислойность изломов черепка. Данные признаки, возможно, свидетельствуют о так называемом «бытовом» обжиге, т.е. случае обожженности поверхности сосудов в результате их использования в быту [32, c. 100,104$]$. Иногда сажистый налет фиксировался в пустотах излома черепка, а также между спаями «строительных элементов», более густо концентрируясь ближе к внутренней стенке сосуда, что, повидимому, связано с проникновением в поры керамики приготавливаемой жидкой пищи. Однако для более убедительной аргументации требуется методическая разработка вопроса и проведение серии экспериментов, направленных на выявление причин появления таких цветовых изменений и связь выявленных признаков с бытовым использованием [33, с. 236].

ПОГРЕБАЛЬНАЯ ПОСУДА. В ряде случаев посуду специально изготавливали для погребальной церемонии. Так сосуд из могильника Прохоровка I (к. Б п. 6) (рис. 1:20) не имел нагара, был сформован крайне небрежно из плохо промешанной формовочной массы глина+шамот+навоз, имел грубые естественные железистые включения в исходном пластичном сырье (размерами до 1 см) и слабое соединение между строительными элементами. Он был подвергнут кратковременному воздействию температур менее $450^{\circ} \mathrm{C}$, о чем свидетельствует проверка на низкотемпературный обжиг: фрагмент при пребывании в воде в течение 1 минуты превратился в глинистую массу из которой можно было скатать жгутик [10, с. 245].

Косвенные признаки, указывающие на специальное изготовление керамических предметов для религиозной церемонии, были зафиксированы в захоронении рубежа VI-V вв. до н.э. у с. Пятилетка [34, с. 168-171]. В погребении «женщины-жрицы» наряду с другими предметами культа были найдены сосуд и коническое пряслице (рис. 1: 21, 23). Эти керамические вещи имели схожую орнаментацию из пиктограмм и знаков (рис. 1: 22, 24), а также были изготовлены из аналогичного исходного пластичного сырья и общего состава формовочной массы

4 Ранее исследователи относили чашу к бронзовому веку. Впервые обратила внимание на сомнительное отнесение чаши к ямной культуре Н.П. Салугина. Курган 2 могильника Изобильное I содержал 5 впускных сарматских захоронений, основные центральные ямы были пустыми и ориентированы по линии С-Ю и С3-ЮВ, следы охры или другие свидетельства отнесения кургана к ямной культуре отсутствовали. Орнамент, форма и состав формовочной массы сосуда, из которого была сделана «чаша», склоняют к предположению, что этот сосуд относится к раннему железному веку. Появление керамики подобного типа в южном Приурапье связано_ мигрантами из Заурапья 
(глина+шамот+органический раствор), нагар внутри сосуда отсутствовал.

Таким образом, к признакам специального изготовления сарматской керамики для обряда погребения следует отнести: 1) использование неочищенного исходного пластичного сырья с грубыми естественным примесями; 2) некачественный промес формовочной масс, проявляющийся в неравномерном распределении частиц искусственно введенных примесей; 3) небрежность в изготовлении формы; 4) кратковременное воздействие температур ниже $450^{\circ} \mathrm{C}$ при обжиге; 5) отсутствие нагара на стенках сосуда; 6) отсутствие следов ремонта.

Следует отметить, что каждый из перечисленных признаков в отдельности не является веским аргументом в пользу доказательства о неиспользовании сосуда в быту перед помещением в могилу. Необходимо учитывать сочетание признаков для того, чтобы сделать более аргументированным данное предположение.

Наличие или отсутствие признаков бытового использования не зависело от типа сосуда. Выделить «кухонную» и «столовую» посуду среди сарматской керамики, помещенной в погребения, представляется затруднительным. Более четко связать функциональное назначение сосуда с формой можно с определенными типами курильниц (рис. 1: 15-18; фото 1: 3-4), кувшинами с высоким горлом и ручкой, сосудами со сливом по краю, горшками с трубчатым носиком-сливом. Если курильницы использовались при проведении каких-то религиозных обрядов, иногда со сжиганием трав или других каких-то веществ, то назначение остальных перечисленных типов сосудов связано с хранением и розливом жидкости.

Проведенные экспериментальные работы по моделированию сосуда с трубчатым носиком-сливом на плече (рис. 1: 26-27) показали, что жидкость не выливается из носика, если не достигает его уровня, т.е. в том случае, когда сосуд наполнен на 2/3. Наполнить сосуд полностью без выливания было возможно при условии увеличения длины носика или плотном затыкании его пробкой. В последнем случае при вынимании пробки из носика, жидкость начинала выливаться из сосуда и стекать по стенкам, при этом сосуд невозможно было наклонить.

Предположение, что отверстие трубчатого носика-слива могло служить для крепления длинной деревянной ручки, не выдерживает критики. Действительно, используя такую ручку, плотно вставленную в отверстие, сосуд можно было перемещать при приготовлении пищи на костре, но в керамике этого типа, как правило, нагар отсутствует, а их громоздкость препятствует свободному манипулированию. В погребениях такие сосуды находят без пробок, следы дерева внутри трубчатых носиков также ни разу не встречены. Скорее всего, сосуды данного типа служили именно для хранения и розлива жидкости.

Подводя итоги, следует отметить, что керамика у сарматов Южного Приуралья и Западного Казахстана имела многофункциональное назначение. Она активно использовалась как в хозяйстве, так и в религиозных церемониях. В могилы могли помещать специально подготовленные для обряда погребения сосуды, а также уже использованную в быту посуду, в том числе реставрированную. Выделение признаков бытового использования керамики относится к методическому вопросу, нуждающемуся в дальнейшей дополнительной разработке.

\section{СПИСОК ЛИТЕРАТУРЫ}

1. Самашев 3., Кушербаев К, Аманшаев Е, Астафьев А. Сокровища Устюрта и Манкыстау. Алматы, 2007.

2. Сокровища сарматских вождей (материалы раскопок Филипповских курганов) / под общей редакцией Л.Т. Яблонского. Оренбург, 2008.

3. Моргунова Н.Л., Гольева А.А., Краева Л.А., Мещеряков Д.В., Турецкий М.А., Халяпин М.В., Хохлова О.С. Шумаевские курганы. Оренбург: Издво ОГПУ, 2003.

4. Сентенс Б. Керамика. Путеводитель по традиционным техникам мира. М., 2005.

5. Демкин В.А., Рысков Я.Г. Реконструкция погребальной пищи в курганных захоронениях бронзового и раннежелезного веков // Курганы левобережного Илека. М., 1994. Вып. 2.

6. Бобринский А.А. Гончарство Восточной Европы: Источники и методы изучения. М.: Наука, 1978.

7. Бобринский А.А. Гончарная технология как объект историко-культурного изучения // Актуальные проблемы изучения древнего гончарства. Самара: Изд-во СамГПУ, 1999.

8. Краева Л.А. Гончарство ранних кочевников Южного Приуралья в VI-I вв. до н.э.: Автореф. дис. ... канд. ист. наук. М., 2008.

9. Краева Л.А. Технология изготовления керамики из погребений раннесарматской культуры Южного Приуралья // Археология, этнография и антропология Евразии. 2011. № 4 (48). С. 51-60.

10. Краева Л.А. Технология изготовления лепной керамики из могильника Прохоровка // Л.Т. Яблонский Прохоровка. У истоков Сарматской археологии. M., 2010. С. 231-251.

11. Курганы левобережного Илека. М., 1995. Вып. 3.

12. Смирнов К.Ф. Курильницы и туалетные сосудики Азиатской Сарматии // Кавказ и Восточная Европа в древности. М., 1973.

13. Моргунова Н.Л., Мещеряков Д.В. «Прохоровские» погребения V Бердянского могильника // Археологические памятники Оренбуржья. Оренбург, 1999. Вып. 3.

14. Краева Л.А. Технология изготовления керамики из «прохоровских» погребений на р. Бердянка // Раннесарматская культура: формирование, развитие, 
хронология. Самара: Изд-во СНЦ РАН, 2000. Вып. 2.

15. Пшеничнюк А.Х. Отчет о раскопках филипповских курганов в Илекском районе Оренбургской области в 1987 году. Уфа, 1988. // Архив ИА РАН.

16. Мещеряков Д.В. Впускные погребения сарматской культуры в курганах на р. Илек // Археологические памятники Оренбуржья. Оренбург: Изд-во ОГПУ, 1996. Вып. 1.

17. Моргунова Н.Л., Краева Л.А. Курганная группа Акоба II // Археологические памятники Оренбуржья. Оренбург: Изд-во ОГПУ, 2012. С. 156-199.

18. Краева Л.А. Сарматский ритуальный сосуд из второго курганного могильника у с. Акоба // Известия Самарского научного центра Российской академии наук. Спец. вып.: Актуальные проблемы истории и археологии. Самара, 2006.

19. Зиберт Э.В. Сосуды из коровьего вымени в коллекциях Музея антропологии и этнографии Академии Наук СССР // Сборник Музея антропологии и этнографии. Т. ХIV. М.-Л., 1953.

20. Руденко С.И. Башкиры. Историко-этнографические очерки. М.-Л., 1955.

21. Федоров В.К. О функциональном назначении так называемых «савроматских жертвенников» Южного Приуралья // Уфимский археологический вестник. Вып. 3. Уфа, 2001.

22. Очир-Горяева М. О возможном назначении парных бронзовых котлов у кочевников раннего железного века Евразии // Археологические памятники раннего железного века юга России. М., 2004.

23. Идес И., Бранд А. Записки о русском посольстве в Китае (1692-1695). М., 1967.

24. Пещерева Е.М. Гончарное производство Средней Азии. М., 1959

25. Гутков А.И. О традиции ремонта глиняной посуды // Археологический источник и моделирование древних технологий. Челябинск, 2000.
26. Яблонский Л.Т., Мещеряков Д.В. Доследование курганного могильника у д. Прохоровка // Ранние кочевники Волго-Уральского региона. Оренбург, 2008.

27. Боталов С.Г., Гуцалов С.Ю. Гунно-сарматы Урало-казахстанских степей. Челябинск: Рифей, 2000.

28. Краева Л.А., Мещеряков Д.В., Моргунова Н.Л. Одиночный курган у с. Благославенка // Археологические памятники Оренбуржья. Оренбург: Изд-во ОГПУ, 2000. Вып. IV.

29. Бобринский А.А. К методике изучения обжига керамики // Первая кубанская археологическая конференция. Тезисы докл. Краснодар, 1989.

30. Турецкий М.А. Отчет о раскопках курганных могильников у с. Изобильное Соль-Илецкого района Оренбургской области в 1993 г. // Архив ИА РАН. P-1. № 18708 .

31. Богданов С.В. Эпоха меди степного Приуралья. Екатеринбург: УрО РАН, 2004.

32. Медведев В.Е., Цетлин Ю.Б. Технико-технологический анализ древнейшей керамики Приамурья (13-10 тыс. л.н.) // Археология, этнография и антропология Евразии. № 2 (54). 2013.

33. Цетлин Ю.Б. Фундаментальные проблемы изучения гончарства // Древнее гончарство: итоги и перспективы изучения. М.: ИА РАН, 2010.

34. Краева Л.А., Богданов С.В. Сарматские погребения могильника у с. Пятилетка // Археологические памятники Оренбуржья. Оренбург: Изд-во ОГПУ, 2000. Вып. IV.

Работа выполнена при поддержке Министерства образования и науки Российской Федерации (задание «33.1471. 2014К» на выполнение научноисследовательской работы в рамках проектной части государственного задания в сфере научной деятельности) и гранта Комитета науки Министерства образования и науки Республики Казахстан (проект 2589/ГФ4) 


\section{ИЛЛЮСТРАЦИИ}
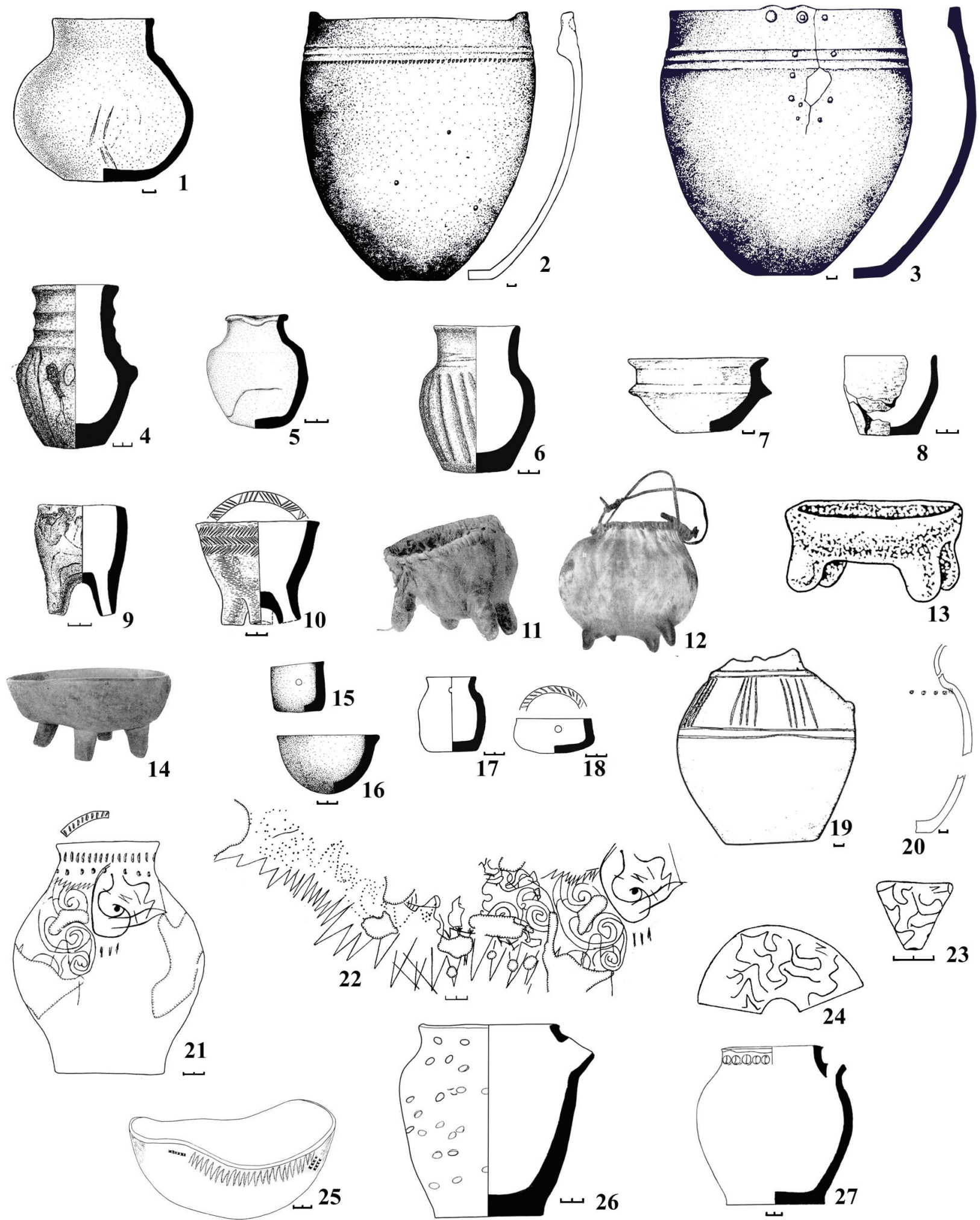

Рисунок 1 - Керамика ранних кочевников Южного Приуралья и Западного Казахстана: 1 - Шумаево 2 к. 9 п. 7; 2-3 - Шумаево 1 к. 4 п. 1; 4 - Шумаево 2 к. 9 п. 4 с. 1; 5- Прохоровка 1 к. 4 п. 2 с. 2; 6 - Покровка 2 к. 8 п. 10 с. 2; 7 - Бердянка к. 5 п. 3; 8 - Линевка ОК п. 3; 9 - Акоба 2 к. 1 п. 3; 10 - Филипповка к. 7; 15-16 - Шумаево1 к. 3 п. 2 с. 3, 2; 17 - Мечет-Сай к. 9 п. 1;18 - Чкаловский к. 4 п. 9; 19 - Благославенка ОК п. 4; 20 - Прохоровка 1 к. Б п. 6; 21-22 - Пятилетка к. 4 п. 1 (сосуд); 23-24 - Пятилетка к. 4 п. 1 (пряслице); 25 - Изобильное 1 к. 2 ров; 26 - Липовка к. 9 п. 3; 27 - Барышников к. 1 п. 2.

Сосуды из вымени животных и их имитации: 11-12 - сосуды индейцев арауканов из коровьего вымени; 13 савроматский каменный жертвенник (Гирьял к. 2); 14 - деревянный сосуд индейцев арауканов. 

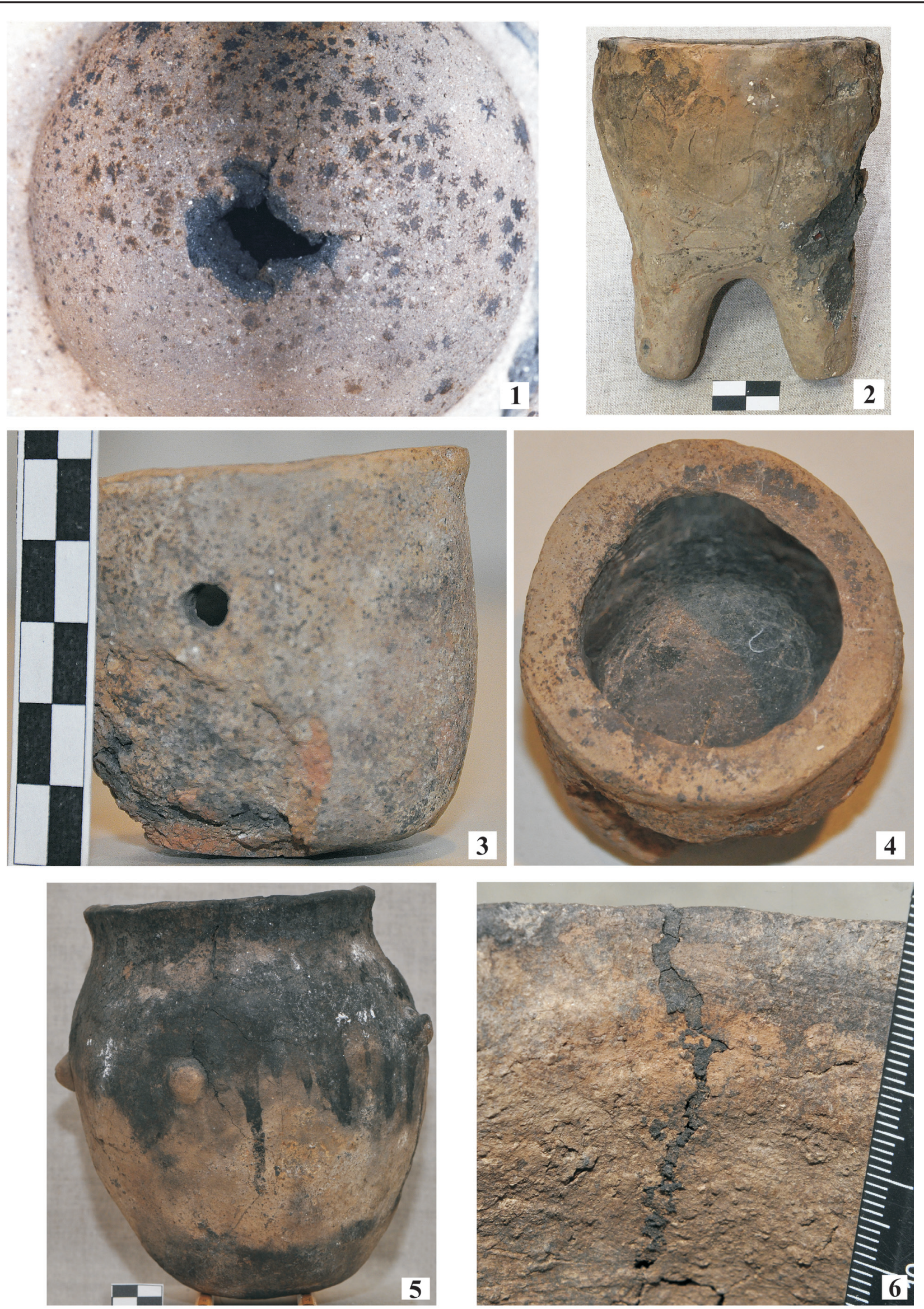

Фото 1 - 1 - внутренняя поверхность миски (Бердянка к. 5 п. 3); 2 - внешняя поверхность (Акоба 2 к. 1 п. 3); 3-4- внутренняя и внешняя поверхности курильницы (Шумаево1 к. 3 п. 2 с. 3); 5-6 - внешняя поверхность и замазка трещины (Целинный 1 к. 32). 1-4 - ОГПУ; 5-6 - АОИКМ. 


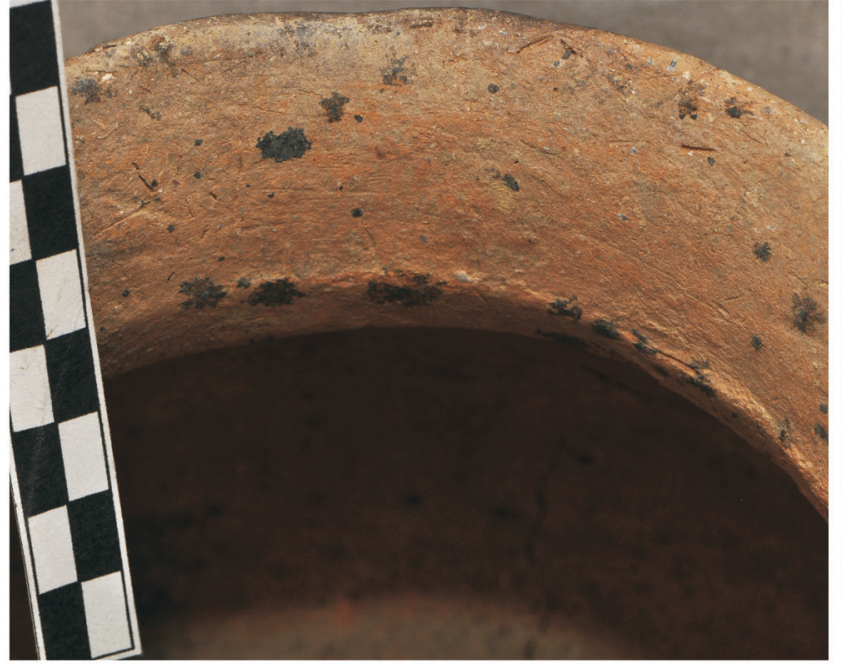

1

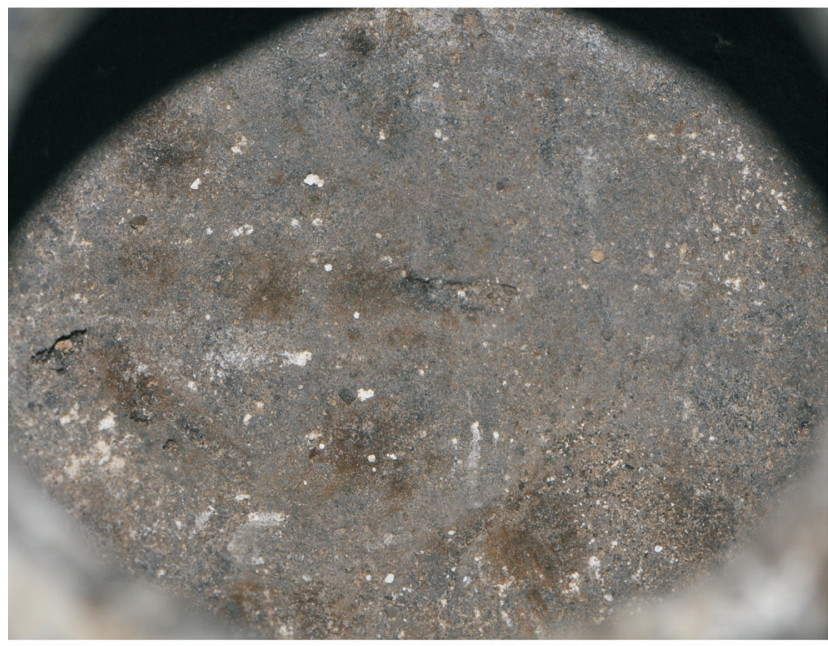



2

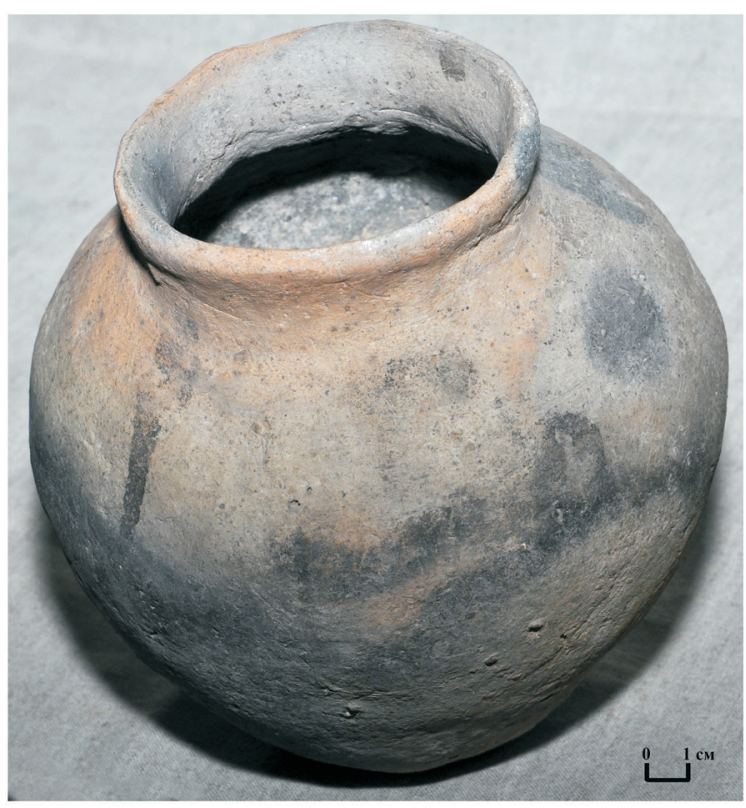

4

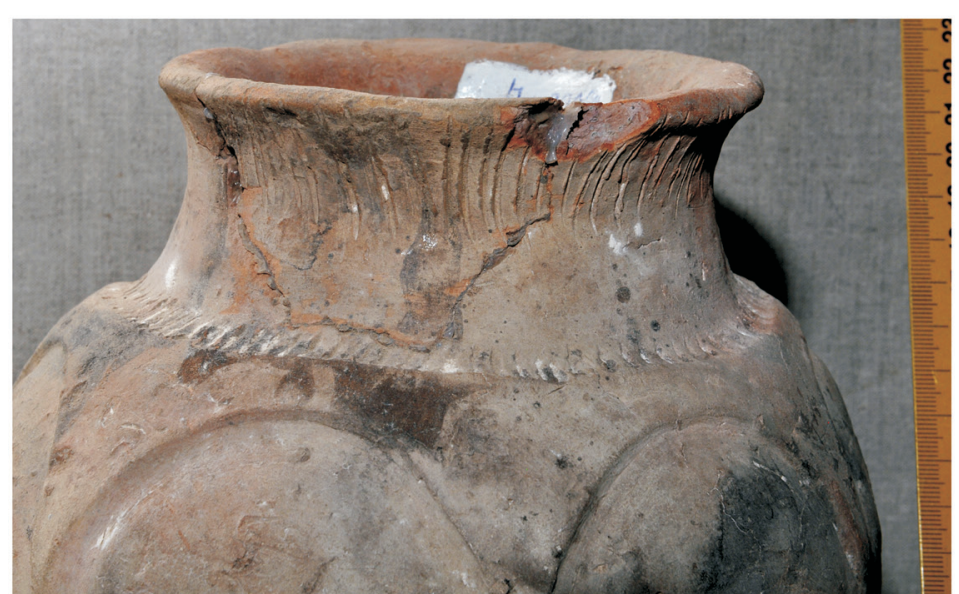

5



6

Фото 2 - Пятна на внутренней и внешней поверхности сосудов: 1 - внутренняя часть венчика сосуда из АОИКМ; 2 - внешняя часть венчика (Облавка 1 к. 1 п. 11); 3 - внутренняя поверхность дна сосуда (Облавка 1 к. 1 п. 8 яма 2); 4-5 - следы пятнистого обваривания: (4 - Кушум 1 к.1 п. 2; 5 - Аксай 3 к. 5 п. 1); 6 - отверстия для ремонта и нагар на внешней поверхности сосуда (урочище Узункуль). 1 - АОИКМ; 2, 4, 6 - ЗКОИКМ; 3, 5 - ЗКОЦИА 


\title{
HOUSEHOLD AND SACRED USE OF THE POTTERY BY THE SARMATIAN TRIBES OF THE SOUTHERN URALS AND WESTERN KAZAKHSTAN
}

(C) 2015

\author{
L.A.Kraeva, candidate of Historical Sciences \\ Orenburg state pedagogical university, Orenburg (Russia)
}

\begin{abstract}
The article deals with the pottery from the Sarmatian burial grounds of the Southern Urals and Western Kazakhstan. Pottery was placed in the graves of the representatives of all social stratums of the nomadic population. In more expensive imported dishes were usually placed. Sarmatian ceramics was actively used both in household and in religious ceremonies. Specially produced vessels for burial rites are found in the graves, as well as utensils already used in the household, including those repaired. The author points out the signs which prove that the pottery had been in household use before being placed in the grave: the presence of soot on the inner and outer walls of the vessels; grease stains and traces of boiling over liquid food; repair marks; (broken handles, chipped edges of the vessels, etc.); scuff marks and homemade polishing; the change of color on the surface the vessel and on the layers of the potsherds. The characteristics proving that the pottery was specially manufactured burial rites include: the use of raw materials with rough natural impurities; poor quality battering (uneven distribution of tempers); negligence in the moulding; short-term exposure to temperatures below $450{ }^{\circ} \mathrm{C}$ during firing;) the absence of soot on the walls of the vessel; the absence of repair marks.

The examination of the surface of the vessels and experimental work let the author make an assumption about the functional use of some types of pottery.

Keywords: pottery; sarmatians; Southern Urals; Western Kazakhstan; vessels specially prepared for the burial rite; household use; sacred use.
\end{abstract}

\section{УДК 902 \\ ПЕТРОГРАФИЧЕСКИЙ АНАЛИЗ В ОЦЕНКЕ ФОРМОВОЧНЫХ МАСС ПРИ ИЗУЧЕНИИ ДРЕВНЕЙ ГЛИНЯНОЙ ПОСУДЫ}

(C) 2015
M.A. Кулькова, кандидат геолого-минералогических наук, доцент кафедры геологии и геоэкологии Российский государственный педагогический университет им. А.И. Гериена, Санкт-Петербург (Россия)

\begin{abstract}
Аннотацุия. В статье рассматривается ряд вопросов, касающихся петрографического метода исследования древней керамики. На основе литературных данных обсуждаются различные характеристики древней керамики по данным петрографического анализа, которые дают возможность оценить источники сырья, состав керамического теста, условия и температуру обжига и, в конечном счете, понять технологический процесс изготовления древней посуды, а также установить различия в традициях изготовления керамики и появление импортных изделий. Процесс изготовления глиняного сосуда начинается с выбора и подготовки глиняного теста (глины и отощителя) и продолжается через последовательность различных техник (формовки сосуда, обработки поверхности) и наконец, обжига. В шлифах могут быть определены различные характеристики керамического материала: природа и характеристики непластичных включений (минеральный состав, процентное содержание, размеры, форма, распределение и ориентация отдельных частиц); текстурные и оптические характеристики глинистой матрицы (двулучепреломление, цвет); форма, количество и ориентация пустот; особенности обработки поверхности, декорация. Информация, полученная по петрографии о керамической структуре и материалам, используемым для создания глиняного изделия, позволяет выяснить принципы, которые гончар применял для выбора и переработки глинистого сырья, лепки сосуда, условий обжига и создания окончательного изделия. Понимание природы этих процессов может быть важным для нашего знания о прошлом, особенно в отношении источников минерального сырья, пространственного распределения торговых связей, специализации производственных технологий и развития технологий.

Ключевые слова: петрография; древняя керамика; шамот; отощитель; источники сырья; составы формовочных масс.
\end{abstract}

\section{Введение}

Керамика является важным артефактом, которая сохранила информацию о древних сообществах. Форма и декоративные детали глиняного сосуда представляют собой конечную фазу в комплексе технологической цепочки [1]. Процесс изготовления глиняного сосуда начинается с выбора и подготовки глиняного теста (глины и отощителя) и продолжается через последовательность различных техник (формовки сосуда, обработки поверхности) и наконец, 